\section{Congenital Disorder of Glycosylation: Clinical and Molecular Characteristics of 9 Patients from Turkey}

\author{
Konjenital Glikozilasyon Defektleri: Türkiye'den 9 \\ Hastanın Klinik ve Moleküler Özellikleri
}

\section{Melis Köse $\odot$ Engin Köse $\odot$ Mehtap Kağnıcı $\odot$ Hande Gazeteci Tekin $\odot$ Burçin Özen $\odot$ Taha Resid Özdemir $\odot$ Özgür Kırbıyık $\odot$ Hüseyin Onay $\odot$ Ünsal Yılmaz $\odot$ Aycan Ünalp $\odot$}

\begin{abstract}
Objective: Congenital defects of glycosylation (CDG) belongs to a group of genetic diseases that lead to impairment in protein, lipid glycosylation and glycosylphosphatidylinositol synthesis. More than 140 types of CDG have been identified and the number is increasing day by day. Since glycosylation is very important for post-translational process and glycosylation is required for half of the proteins in human organism to be able to exert an effect, causes the disease to have an extremely wide clinical spectrum in affected patients. Our aim is to share the clinical features of our patients with CDG and contribute to increase in the awareness of this disease group with highly heterogeneous clinical spectrum.

Method: Nine patients from 9 families whose molecular and biochemical diagnosis was confirmed were included in the study. All patients were evaluated by a specialist.in pediatric metabolism Laboratory analysis results and clinical features were obtained from hospital records. Our study presents clinical, biochemical and molecular properties of 9 patients.

Results: The patients were detected as having PMM2-CDG (CDG la) ( $n=4)$, MPI-CDG (CDG Ib) (n=1), ALG3CDG (CDG Id) (n=1), ALG1-CDG (CDG Ik) (n=1), DOLK-CDG (CDG Im) $(n=1)$ and COG4-CDG (CDG Ilj) (n=1). Sialotransferrin electrophoresis could be performed in 8 of 9 patients. Six patients were diagnosed using high- throughout next -generation sequencing technologies. In all of our patients previously indentified variants have been detected.

Conclusion: Our study is one of the first CDG case series presented in our country. CDG should be kept in mind as an important preliminary diagnosis in patients with multisystemic involvement and neurological findings.
\end{abstract}

Keywords: CDG, congenital disorder of glycosylation, PMM2, MPI, ALG1, ALG3, DOLK, COG4, next-generation sequence analysis, sialotransferrin electrophoresis

\section{Öz}

Amaç: Konjenital glikozilasyon defektleri (CDG), protein ve lipid glikozilasyonu ve glikozilfosfotidilinositol sentezinde bozukluğa yol açan bir grup genetik hastalıktır. Yüz kırktan fazla CDG tipi tanımlanmıştır ve sayı her geçen gün artmaktadır. Glikozilasyonun post-translasyonel süreç için çok önemli olması ve insan organizmasındaki proteinlerinin yarısının etki olabilmesi için glikozillenmesi gerekliliği hastaların son derece geniş bir klinik spektruma neden olmaktadır. Çalışmamızın amacı; CDG tanısı ile izlediğimiz hastaların klinik özelliklerinin paylaşılması ve son derece heterojen klinik fenotipe sahip bu hastalık grubuna ait farkındalığın arttırılmasın katkıda bulunmaktır.

Yöntem: Moleküler ve biyokimyasal olarak tanısı doğrulanan 9 aileden 9 hasta çalışmaya dahil edilmiş ve tüm hastalar çocuk metabolizma uzmanı tarafından değerlendirilmiştir. Laboratuar analiz sonuçları ve klinik özellikleri hastane kayıtlarından elde edilmiştir. Çalışmamız; 9 hastanın klinik, biyokimyasal ve moleküler özelliklerini sunmaktadır.

Bulgular: Dört hasta PMM2-CDG (CDG la), 1 hasta MPI-CDG (CDG Ib), 1 hasta ALG3-CDG (CDG Id), 1 hasta ALG1-CDG (CDG Ik), 1 hasta DOLK-CDG (CDG Im), 1 hasta COG4-CDG (CDG Ilj) olarak saptanmıştır. Hastalarımızın tamamında sialotransferrin elektroforezi yapılabilmiștir. Altı hasta yüksek çıktılı next generation sequencing teknolojileri ile moleküler tanı almıştır. Hastalarımızın tamamında literatürde daha önce tanımlanmış varyantlar saptanmıştır.

Sonuç: Çalışmamız, ülkemizden sunulan ilk CDG olgu serilerinden birisi olma özelliğini taşımaktadır. Multisistemik tutulumu olan, nörolojik bulguları olan hastalarda CDG önemli bir ön tanı olarak akılda tutulmalıdır.

Anahtar kelimeler: CDG, konjenital glikozilasyon defektleri, PMM2, MPI, ALG1, ALG3, DOLK, COG4, yeni nesil dizi analizi, sialotransferrin elektroforezi
Received/Geliș: 06.04.2020

Accepted/Kabul: 31.05 .2020

Published Online: 22.12.2020

Melis Kose İzmir Katip Çelebi Üniversitesi Tip Fakültesi, Çocuk Sağlığı ve Hastalıkları Anabilim Dal, Çocuk Metabolizma Ünitesi, İmir - Türkiye drmelisdemir@gmail.com ORCID: 0000-0003-2255-3725

E. Köse 0000-0001-7238-2894 Urfa Eğitim Araştırma Hastanesi, Çocuk Metabolizma ve Beslenme Bölümü, Urfa, Türkiye

M. Kağnıcı 0000-0002-7071-9200 Sağlık Bilimleri Üniversitesi, Antalya

Eğitim Araştırma Hastanesi, Çocuk Metabolizma Bölümü, Antalya, Türkiye

H. Gazeteci Tekin 0000-0002-4407-164X izmir Çiğli Ĕgitim Araştırma Hastanesi, Çocuk Nöroloji Bölümü, Izmir, Türkiye

B. Özen 0000-0003-1975-2299 Sağlık Bilimleri Üniversitesi, Tepecik Eğitim ve Araștırma Hastanesi, Çocuk Sağlığı ve Hastalıkları Bölümü, İzmir, Türkiye

T.R. Özdemir 0000-0003-4870-6945

Ö. Kırbıyık 0000-0003-1333-2007

Sağlık Bilimleri Üniversitesi, Tepecik Eğitim ve Araştırma Hastanesi, Genetik Bölümü, İzmir, Türkiye

H. Onay 0000-0002-0584-8866 Ege Üniversitesi Tıp Fakültesi, Tıbbi Genetik Anabilim Dalı, İzmir, Türkiye

Ü. Yıllmaz 0000-0002-7256-8557

A. Ünalp 0000-0002-3611-5059 Sağlık Bilimleri Üniversitesi, Behçet Uz Çocuk Sağlığı, Hastalıkları ve Cerrahisi Eğitim ve Araştırma Hastanesi, Çocuk Nöroloji Bölümü, İzmir, Türkiye 


\section{INTRODUCTION}

Congenital disorders of glycosylation (CDG) is a group of congenital metabolic diseases that are gradually increasing in incidence day by day after its definition by Jaeken et al. in 1980 for the first time as a carbohydrate- deficient glycoprotein syndrome. Basically, glycosylation occurs as a result of defects formed during the synthesis of glycoproteins or glycolipids and during incorporation of glycans to proteins and lipids ${ }^{(1)}$. Glycosylation is a set of reactions that take place in the participation of monosaccharides in processes during the synthesis, construction, enzymatic reactions or destruction of protein and lipid compounds in all living species. It is the most common and complex type of post-translational modification in the organism ${ }^{(2)}$. Among all genes in the human genome, $2 \%$ encode different stages of glycosylation and $50 \%$ of the human proteome is glycosylated ${ }^{(3)}$.

Glycosylation takes place mainly in the cytosol, endoplasmic reticulum (ER) and the Golgi apparatus. Eight different biochemical pathways are involved in this process; however, the most well-known one is $\mathrm{N}$ - and $\mathrm{O}$ - glycosylation of proteins ${ }^{(4)}$. Congenital disorders of glycosylation disorders are classified in groups as $\mathrm{N}$-glycosylation, O-glycosylation, combined $\mathrm{N}$ - and O-glycosylation disorders, defects of glycolipid and glycosylphosphatidylinositol (GPI) synthesis, multiple glycosylation pathways and other pathways. Protein N-glycosylation defects are the most common ones among different glycosylation disorders. Multiple glycosylation and other glycosylation pathway disorders include some recently identified disorders of vesicular transport, nucleotidesugar transport, and O-mannozylation disorders ${ }^{(5)}$. Probably the most accurate and indisputable aspect of CDG symptomatology is the high phenotypic variability compared to any other congenital metabolic disease. Undoubtedly, the common presence of glycosylation in all cells and its requirement in many biological processes provides the basis for this condition. The clinical phenotype can range from mild to severe and from single organ to multiple system involvement ${ }^{(4,6)}$.
Currently, more than 140 different CDG subtypes have been defined ${ }^{(2)}$. The glycosylation pattern of sialotransferrin was the basis for the first CDG classification. Therefore, the CDG nomenclature was classified as CDG-I and CDG-II. However, the increasing number of CDG subtypes and definition of cases discordant with any glycosylation patterns was the basis for a formulation of a new nomenclature as 'affected gene-CDG'.

Since consanguineous marriage is common in our country, the estimated prevalence of congenital glycosylation defects, a subset of congenital metabolic diseases like all other Mendelian diseases, is also at a high level ${ }^{(7,8)}$. Performance of very important tests in the diagnostic process of CDG related to sialotransferrin glycosylation, apolipoprotein C-III isoelectric focusing (IEF) and N-glycan profile in only a small number of centers cause prolongation of the diagnostic process. In addition, the definitive diagnosis needs molecular confirmation in patients who are tested, which broadens the spectrum of molecular genetic analysis in the diagnosis of the disease. The recent widespread use of new generation sequence analysis techniques has increased the chance of diagnosis of this disease group with many subtypes.

This study presents the clinical, laboratory, molecular features and diagnostic processes of 9 patients with 6 different CDG types. Our aim is to share the clinical features of our patients with CDG and contribute to increase in the awareness of this highly heterogeneous clinical spectrum among pediatricians.

\section{MATERIAL and METHODS}

Nine patients diagnosed to have CDG in pediatric metabolism department were retrospectively evaluated. Demographic findings of the patients, age of onset of the disease, primary symptoms, antenatal and postnatal history, features of medical history, physical examination findings, nutritional features, neurological, hepatogastrointestinal, sensorineural and endocrine manifestations, laboratory data (complete blood count, coagulation parameters, liver transaminases, kidney function tests, thyroid function tests, fasting glucose and insulin levels), 
echocardiography, abdominal ultrasonography, magnetic resonance imaging of the brain, sialotransferrin electrophoresis and results of molecular genetic analysis were recorded. Diagnosis was made using sialotransferrin electrophoresis and molecular genetic methods in all patients however in 6 patients; sialotransferrin electrophoresis was performed after molecular genetic diagnosis was made for the confir-

Table 1. Demographic, clinical, biochemical and molecular findings of patients.

\begin{tabular}{|c|c|c|c|c|c|c|c|c|c|}
\hline & P1 & $\mathbf{P 2}$ & P3 & P4 & P5 & P6 & P7 & P8 & P9 \\
\hline Diagnosis & PMM2 & PMM2 & ALG3 & ALG1 & DOLK & PMM2 & PMM2 & MPI & COG4 \\
\hline Gender & Male & Male & Male & Female & Female & Female & Female & Female & Female \\
\hline Age at onset & $3 \mathrm{~m}$ & $4 \mathrm{~m}$ & Neonate & $2 \mathrm{~m}$ & Neonate & $3 \mathrm{~m}$ & $2 \mathrm{~m}$ & $5 \mathrm{~m}$ & $2 \mathrm{~m}$ \\
\hline Age at diagnosis & $8 \mathrm{~m}$ & $12 \mathrm{~m}$ & $13 \mathrm{~m}$ & $2 \mathrm{~m}$ & - & $16 \mathrm{~m}$ & $19 \mathrm{~m}$ & $54 \mathrm{~m}$ & $36 \mathrm{~m}$ \\
\hline Following time & $23 \mathrm{~m}$ & $9 \mathrm{~m}$ & $38 \mathrm{~m}$ & $1 \mathrm{~m}$ & $18 \mathrm{~d}$ & $21 \mathrm{~m}$ & $16 \mathrm{~m}$ & $9 \mathrm{~m}$ & $41 \mathrm{~m}$ \\
\hline Follow-up & Alive & Alive & Alive & Exitus & Exitus & Exitus & Exitus & Alive & Alive \\
\hline Consanguinity & + & + & + & + & - & + & - & + & + \\
\hline Microcephaly & + & + & + & + & + & + & + & - & + \\
\hline Inverted nipples & + & + & - & - & + & + & + & - & - \\
\hline Abnormal fat distribution & - & + & - & - & - & + & - & + & - \\
\hline Dysmorphic face & + & + & + & + & + & + & + & - & + \\
\hline Intellectual disability & + & + & + & NA & NA & + & + & - & + \\
\hline Hypotonicity & - & + & - & + & + & + & + & - & + \\
\hline Spasticity & + & - & + & - & - & - & - & - & - \\
\hline Epilepsia & + & + & + & + & + & + & + & - & + \\
\hline Neuropathy & - & + & + & NA & NA & + & - & - & + \\
\hline Sensoryneural hearing loss & + & - & + & - & NA & + & - & - & - \\
\hline Strabismus & + & + & + & + & - & + & + & - & + \\
\hline Nystagmus & - & + & - & + & - & + & - & - & - \\
\hline Optic atrophia & - & + & + & + & - & + & + & - & + \\
\hline Retinitis Pigmentosa & - & - & - & - & - & + & + & - & - \\
\hline Colobom & + & - & - & - & - & - & - & - & + \\
\hline Grow retardation & + & + & - & + & - & + & + & + & + \\
\hline Hepatomegalia & - & - & - & - & - & - & - & + & - \\
\hline Hepatic fibrosis & - & - & - & - & - & - & - & + & - \\
\hline Hepatic Failure & - & - & - & - & - & - & - & + & - \\
\hline Diarrhea & - & - & - & - & + & - & - & + & + \\
\hline Protein loosing enteropathy & - & - & - & - & - & - & - & + & - \\
\hline İchtiosis & - & + & - & - & + & - & - & - & - \\
\hline Nonimmun & - & + & - & + & - & + & - & - & - \\
\hline \multicolumn{10}{|l|}{ Hydrops } \\
\hline \multicolumn{10}{|l|}{ Fetalis } \\
\hline Cerebellar & + & + & + & + & + & + & + & - & + \\
\hline \multicolumn{10}{|l|}{ Atrophia } \\
\hline Cardiyomyopathia & + & + & + & + & - & + & - & - & + \\
\hline Kiphosis & - & + & + & - & - & + & - & - & + \\
\hline Scoliosis & + & + & + & - & - & - & + & - & + \\
\hline Chest abnormality & + & - & + & - & - & + & - & - & + \\
\hline Hypoglicemia & - & - & - & + & + & - & - & + & - \\
\hline Hyperinsulinism & - & - & - & + & + & - & + & + & - \\
\hline Prolonged coagulation & - & - & - & + & + & - & - & + & - \\
\hline Protein C,S, ATIII abnormality & - & - & - & - & - & - & - & + & - \\
\hline Hypoalbuminemia & - & - & - & + & - & - & - & + & - \\
\hline Tyroid Function Abnormality & - & + & - & - & - & + & - & + & - \\
\hline Hypocholesterolemia & - & - & - & - & - & - & - & + & - \\
\hline Sialotransferrin & Tip 1 & Tip 1 & Tip 1 & Tip 1 & - & Tip 1 & Tip 1 & Tip 1 & Tip 2 \\
\hline Elektrophoresis Patern & Patern & Patern & Patern & Patern & N.A. & Patern & Patern & Patern & Patern \\
\hline \multirow[t]{3}{*}{ Mutation spectrum } & Hom. & Hom. & Hom. & Hom. & Hom. & Comhtz & Comhtz & Hom. & Hom. \\
\hline & c. $691 \mathrm{G}>\mathrm{A}$ & c. $691 \mathrm{G}>\mathrm{A}$ & c. $165 \mathrm{C}>\mathrm{T}$ & c. $773 \mathrm{C}>\mathrm{T}$ & c. $1558 A>G$ & c. $422 \mathrm{G}>\mathrm{A} /$ & c.647 A>T/ & c. $1193 \mathrm{~T}>\mathrm{C}$ & c. $1647+5 G>A$ \\
\hline & & & & & & c.385 G>A & c. $691 \mathrm{G}>\mathrm{A}$ & & \\
\hline
\end{tabular}

+, finding is present; -, finding is absent; N.A; not available, ATIII; Antitrombin III, TFI; Transferrin izoelectric focusing; m, month; d, day, Hom; homozygous, comhtz; compound heterozygous. 
mation of diagnosis.The segregation analysis of the index case was performed in the mother, father and healthy siblings.

\section{RESULTS}

The female/male ratio of the patients was found as 5/4. Mean age at the onset of symptoms (2.4 \pm 1.5 : median: 2, 0-5 months), and at the time of diagnosis (17.7 \pm 17.1 :median: 13 , range:0-54 months), mean duration of follow-up (17.5 \pm 14.7 : median: 16 , range: 0-41 months), and diagnostic process (15.3 \pm 16.3 : median:12, range:0-49 months), and mean time interval to retrieve expert evaluation of metabolism (12.3 \pm 13.7 : median:10, range:0-42 months) were also recorded. Consanguineous marriage was detected in 7 cases. Death of a sibling with a similar history was present in 4 patients. During the follow-up period, 4 patients died, and 5 patients were still alive at the time of preparation of this article.

Before evaluation of our patients by the metabolism department, the number of applications to other departments ranged between 2 and 5. Most of the patients were diagnosed after an average of 12 months of research. It has been determined that the patients applied to general pediatrics, pediatric neurology and pediatric gastreonterology departments before assessment of their metabolic status. It was observed that 5 out of 9 patients applied to the outpatient clinics of general pediatrics (P2, P3, P7, P8, $\mathrm{P9})$. When the complaints of the patients who applied to outpatient clinics of general pediatrics were examined, the most common ones were seizures (8/9; 88\%), developmental retardation (8/9; 88\%), growth retardation $(8 / 9 ; 88 \%)$, and nutritional problems (5/9; 55\%) In addition, low blood sugar (3/9; $33.3 \%)$; diarrhea $(3 / 9 ; 33.3 \%)$ were also among the complaints of the patients. The most common dysmorphic findings and neurological findings were (hypotonicity, spasticity, developmental retardation [8/9; 88.8\%]), eye abnormalities (strabismus, nystagmus, optic atrophy, retinitis pigmentosa, coloboma [7/9; 77.7\%]), cardiomyopathy (6/9; 66.6\%), bone findings (scoliosis, kyphosis, chest abnormalities $[5 / 9 ; 55.5 \%)$ gastrointestinal system findings (hepa- tomegaly, elevated liver transaminases, liver fibrosis, liver failure, diare [3/9;33.3\%]), non-immune hydrops fetalis (NIHF) $(3 / 9 ; 33.3 \%)$, and coagulopathies ( $3 / 9$; $33.3 \%)$.

The diagnoses of the patients were detected as follows:, PMM2-CDG (CDG la) ( $n=4)$, MPI-CDG (CDG lb) $(n=1)$, ALG3-CDG (CDG Id) ( $n=1)$, ALG1-CDG (CDG Ik) $(n=1)$, DOLK-CDG (CDG Im) (n=1), and COG4-CDG (CDG IIj) ( $n=1)$. Sialotransferrin electrophoresis could be performed in all patients. While, patients were diagnosed by using whole exome sequencing (WES) $(n=4)$, Trusight Inherited Disease ${ }^{\circledR}$ panel (1), and 1 patient with Illumina ${ }^{\circledR}$ Trusight One Sequencing Panel $(n=1)$. All of our patients had variants that were previously identified in the literature. The clinical, laboratory and molecular findings of our patients are summarized in Table 1 . Since our patients had a heterogeneous distribution, our largest subgroup included 4 patients (PMM2-CDG), (Table 1), clinical and laboratory features were arranged to include all the findings we have expected to see in CDG. Three of our patients were among the CDG types that were reported in fewer than 20 cases in the literature (P3, P5, P9).

\section{DISCUSSION}

Congenital disorders of glycosylation (CDG) belong to a clinically and genetically highly heterogeneous group. Since the diagnostic tests are performed in very few centers in our country and uncovering by health insurances is one of the most important factors that complicate the diagnostic process in addition to clinical heterogeneity, the next generation sequence analysis (NGS) methods have become more feasible and the costs have decreased gradually facilitating the diagnostic process in disease groups with many subtypes, allele and locus heterogenities such as CDG. Treatment to change the natural course of the disease is possible in very few subtypes of CDG.

The clinical spectrum of CDG patients is quite wide. However, neurological, dysmorphic and cardiac findings were observed to be more prominent (Table 1). Among 9 patients in this present study, 8 
$(8 / 9 ; 88.8 \%)$ cases manifested at least one neurological finding, and $8(8 / 9,88.8 \%)$ of them had dysmorphic findings. Epilepsy and intellectual disability are present in all patients with neurological findings. Cerebellar atrophy appears as a finding of imaging studies in all 8 patients with neurological findings. This condition is in accordance with previous literature knowledge ${ }^{(9,10)}$. Cardiomyopathy (CMP) is the third most common finding $(6 / 9 ; 66.6 \%)$. Interestingly, there were no other cardiac anomalies other than CMP, especially in the PMM2-CDG group, which was evaluated extensively in both this present study and in the literature because it is the most common group ${ }^{(10-12)}$. Hypertrophic CMP was observed in 2 of our 4 patients in the PMM2-CDG group (2/4; 50\%); however, anatomical defect, pericardial effusion, and related rhythm disturbances, were not seen. In the study of Yıldız et al. ${ }^{(7)}$ presenting 11 PMM2-CDG patients from our country, $36 \%$ of them were reported to have hypertrophic CMP, while $45 \%$ of the cases had additional pericardial effusion. Another finding that was different from the literature in terms of CMP was that none of the cardiac manifestations was seen in our DOLK-CDG patient. In their study, Rush et al. reviewed cases of DOLK-CDG and reported at least one cardiac manifestation, primarily cardiomyopathy in 16 out of 20 patients $(16 / 20,(80 \%)$. In this present series, another finding that is different from the literature results, is that gastrointestinal symptoms were seen in a smaller number of patients, except for the MPI-CDG patient. PMM2-CDG, ALG1-CDG, ALG3-CDG and COG4-CDG which were the types encountered in our patient group were reported to manifest with liver involvement other than the MPI-CDG ${ }^{(13)}$. However, no liver involvement was seen in any of our patients except the patients with MPI-CDG. In this present study any findings of liver involvement were not seen in the majority of cases with PMM2-CDG. In a Frenchbased study evaluating 96 PMM2-CDG patients, $43.1 \%$ of them had elevated liver transaminases. On the other hand, levels of antithrombin III (AT-III), protein $\mathrm{C}$ and protein $\mathrm{S}$ which are among the glycosylated proteins synthesized in the liver and important for the hepatic synthesis were found to be lowered in $33 \%, 31.8 \%$ and $5.4 \%$ of the patients, respectively (12). Both liver transaminases and protein $C, S$, and AT-III levels were normal in all of our PM2-CDG patients and any coagulopathy was not observed.

CDG group shows multisystemic involvement like the other types of inborn errors of metabolism. The fact that the phenotype of diseases is so wide is also of great importance for general pediatricians or other specific branches that are the first physicians who examine these patients. In our patient group, it can be seen that the time for patients to reach department of metabolism can be extended up to 49 months and the patients consulted to 2 to 5 different sections before they came to the metabolism section. When CDG group is considered per se, it is extremely rare, but when evaluated collectively, it is a disease group that has the potential to appear more frequently. For this reason, the recognition of the first signs or common features of the disease by pediatricians is especially important for the treatable groups. Epilepsy, developmental retardation, nutritional abnormalities are the most common conditions followed by hypoglycemia, diarrhea and coagulopathies. When the first admission complaints of patients to the other departments are evaluated epilepsy, developmental retardation, and nutritional abnormalities are the most common condiitons followed by hypoglycemia, diarrhea and coagulopathies. Considering that one of the most important physical examination findings of CDG types other than CDGIb (MPI-CDG) is dysmorphic findings, it should be kept in mind that patients with dysmorphic findings, bleeding disorders, hypoglycemia, neurological findings, gastrointestinal findings must be evaluated in terms of CDG.

When the mutation spectrum of our patients was examined, a total of 18 alleles from 9 families were analyzed. The c.691 G>A variant was detected in 5 alleles and evaluated as the most common variant. However, in our patient group, since 6 different CDG types were detected in 9 patients and the single type detected in more than 1 patient was PMM2-CDG, it would not be possible to specify allele frequency in this present study. In our study, c.691G>A variant was found in $5(5 / 8,62.5 \%)$ out of 8 alleles when 
evaluated among 4 PMM2-CDG patients. As the most common PMM2 variant in the literature, c.422 $\mathrm{G}>\mathrm{A}$ variant, was detected in 1 allele in our study. This is contradictory to the literature findings and might be due to the low number of patients in this present study. However, c.691 G> A variant was detected most frequently by Yıldız et al. ${ }^{(7)}$ in their study including 11 Turkish patients. Although this suggests that the prevalence of this variant mentioned above might be higher in the Turkish community compared to other societies, no further interpretation can be made due to the inadequate number of patients and in-house data ${ }^{(12,13)}$.

As diagnostic processes of the patients, WES was used in 4, hereditary disease panels and next generation sequencing technique in 2 patients. In 4 patients, we were able to reach a preliminary diagnosis by sialotransferrin electrophoresis before the molecular diagnosis was achieved. In 5 patients, verification of the diagnosis and reverse phenotyping were performed using silaotransferrin electrophoresis following genetic diagnosis. An important indication for the use of high-throughout NGS techniques (WES and inherited panel) in 6 of our patients was probably the high locus and phenotypic heterogeneities of the CDG group. Sixty new CDG types have been identified using high- throughout NGS techniques at many centers so the laboratory costs are coming down ${ }^{(14)}$. Performing molecular genetic technologies are gradually getting easier at a faster pace. However, since other tests including sialotransferrin electrophoresis and biochemical verification tests of CDG such as apolipoprotein C-III isoelectric focusing (IEF) and $\mathrm{N}$-glycan profile can only be performed in very few reliable centers, it is difficult to access to these tests and thus the demand for molecular analysis increases.

\section{CONCLUSION}

Since consanguineous marriages are highly prevalent in this country, the incidence of CDG group diseases, as all other autosomal recessive diseases is expected to be higher. Interestingly, however, there is no other study published in the literature on this issue apart from individual case reports and very few case series. However, many studies in the literature have shown the presence of cases of Turkish origin. Although our series has few and heterogeneously distributed cases compared to other series in the literature, it is one of the first case series presented from this country.

Ethics Committee Approval: T.C. İzmir Katip Çelebi University Rectorate Non-Interventional Clinical Research Ethics Committee approval was obtained (03.12.2019/272).

\section{Conflict of Interest: None.}

Funding: None.

Informed Consent: Receipt.

\section{REFERENCES}

1. Jaeken J. Congenital disorders of glycosylation Handbook of Clinical Neurology, Oliver Dulac, Meryse Lansonde, and Harvey B. Sarnat eds. Pediatric Neurology Part III. Vol. 113 (3rd series). Elsevier 2013: p1737-43. https://doi.org/10.1016/B978-0-444-59565-2.00044-7

2. Pascoal C, FranciscoR, Ferro T, Dos Reis Ferreira, JaekenJ, Videira PA. CDG and immune response: From bedside to bench and back. J Inherited Metab Dis. 2020;43:90-124. https://doi.org/10.1002/jimd.12126

3. Ng BG, Freeze HH. Perspectives on Glycosylation and its Congenital Disorders. Trends Genet. 2018;34(6):466-76. https://doi.org/10.1016/j.tig.2018.03.002

4. Perez-Cerda C, Giros M.L, Serrano M, Ecay M.J, Gort L, Perez Duenas B et al. Population-Based Study on Congenital Disorders of Protein N- and Combined with O-glycosylation Experience in Clinical and Genetic Diagnosis. J. Pediatr. 2017 Apr;183:170-7. https://doi.org/10.1016/j.jpeds.2016.12.060

5. Brasil S, Pascoal C, Francisko R, Margues-da-Silva D, Andreotti $\mathrm{G}$ et al. CDG Therapies: From Bench to Bedside. Int J Mol Sci. 2018 Apr 27;19(5): 1304-51. https://doi.org/10.3390/ijms19051304

6. Jaeken J, Peanne R. What is new in CDG? J. Inherit. Metab. Dis. 2017 Jul;40(4):569-86. https://doi.org/10.1007/s10545-017-0050-6

7. Yıldız Y, Arslan M, Çelik G, Kasapkara ÇS, Ceylaner S, Dursun A et al. Genotypes and estimated prevalence of phosphomannomutase 2 deficiency in Turkey differ significantly from those in Europe. Am J Med Genet A. 2020;182(4):705-12. https://doi.org/10.1002/ajmg.a.61488

8. Koc I. Prevalence and sociodemographic correlates of consanguineous marriages in Turkey. J Biosoc Sci. 2008;40(1):13748.

https://doi.org/10.1017/S002193200700226X

9. Scott K, Gadomski T, Kozicz T, Morava E. Congenital disorders of glycosylation: New defects and still counting. Journal of Inherited Metabolic Disease. J Inherit Metab Dis. 2014;37(4):609-17. 
https://doi.org/10.1007/s10545-014-9720-9

10. Freeze $\mathrm{HH}$, Eklund EA, Ng BG, Patterson MC. Neurological aspects of human glycosylation disorders. Annu Rev neurosci. 2015;38:105-25.

https://doi.org/10.1146/annurev-neuro-071714-034019

11. Marques da Silva D, Francisco $R$, Webster D, Dos Reis Ferreira, Jaeken J, Pulinilkunnil T.Cardiac complications of congenital disorders of glycosylation (CDG): a systematic review of the literature. J Inherit Metab Dis. 2017;40(5):65772.

https://doi.org/10.1007/s10545-017-0066-y

12. Schiff M, Roda C, Monin ML, Arion A, Barth M, Bednarek N et al. Clinical, laboratory and molecular findings and longterm follo-up data in 96 French patients with PMM2-CDG (phosphomannomutase 2 congenital disorder of glycosylation) and review of the literature.J Med Genet. 2017;54(12):84351. https://doi.org/10.1136/jmedgenet-2017-104903

13. Marques da Silva D, Dos Reis Ferreira, Monticelli $M$, Janeiro P, Videira PA, Witters P, Jaeken J, Cassiman D. Liver involvement in congenital disorders of glycosylation (CDG). A systematic review of the literature. J Inherit Metab Dis. 2017;40(2):195-207. https://doi.org/10.1007/s10545-016-0012-4

14. Ng BG, Freeze HH. Perspectives on Glycosylation and its Congenital Disorders. Trends Genet. 2018;34(6):466-76. https://doi.org/10.1016/j.tig.2018.03.002 